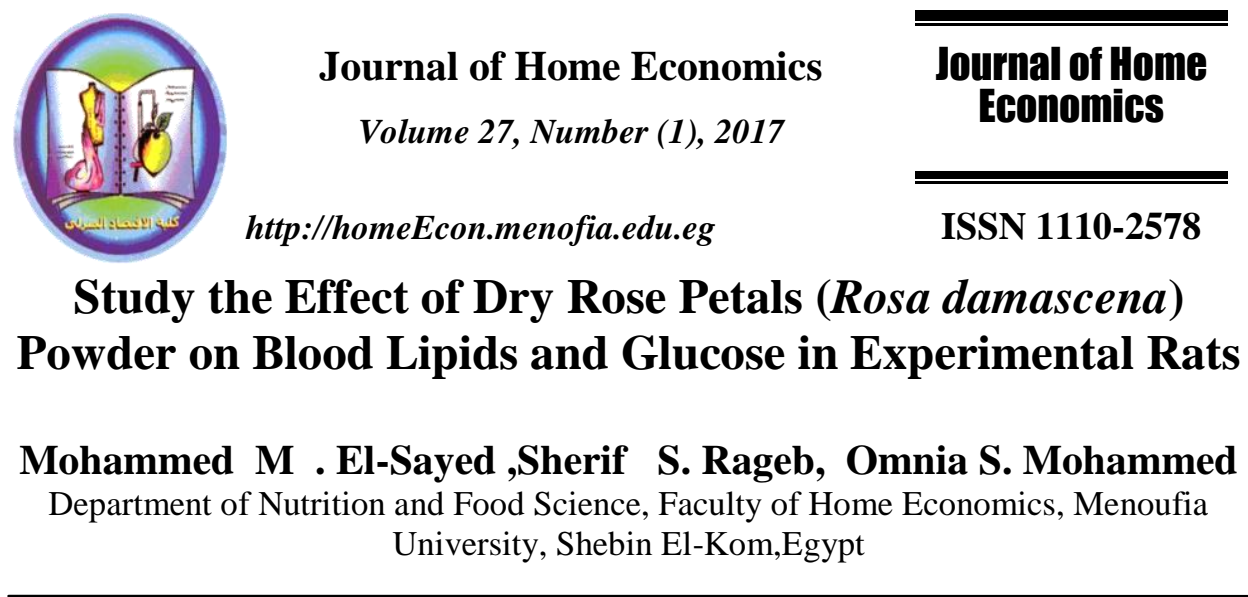

\begin{abstract}
:
This study was conduced to investigate the effect of rose petals (Rosa damascena) powder (RPP) on blood lipids and glucose in experimental rats. Fifty-Four a dult male albino rats weighting $150 \pm 10 \mathrm{~g}$, were used, and divided into three main groups ,First group (5 rats) fed on basal diet as control (-),Second group was induced diabetes by aloxan $(150 \mathrm{mg} / \mathrm{kg})$, third group was induced hyperlipidemia by fed rats on diet containing high lipids( basal diet $+20 \%$ animal fat sheep's tail) for three consecutive weeks . Diabetic and hyperlipidmic rats groups divided into four sub groups, srats per each two of them were diabetic and hyperlipidimic control positive. While the other groups fed a basal diet after replacing 1, 2.5 and 5\% RPP and feeding continued for 30 days. After the treatment, body weight, feed intake (FI),(FER) and blood samples were measured and serum glucose, triglyceride, total cholesterol ,LDL-C, AST, ALT and ALP levels were determinid, while HDL-C and VLDL-C Were calculatedand Histopathological structure of liver has been evaluated. The obtained results revealed that feeding on RPP caused significant $(\mathrm{P} \leq 0.05)$ improvements in weight gain, FI, FER , HDLc, ,but with significant $(\mathrm{P} \leq 0.05)$ decreases in the rest of the parameters as compared with control (+ve) group. Histopathological investigations confirmed the biochemical changes in rats serum . It could be concluded that rosa petals powder was effective in protecting against diabetic and hyperlipidimic rats not only decreased the level of serum glucose but also has beneficial effect on serum lipids and liver functions .Therefore, we recommended the RPP tested plant by a moderate amount $(5 \%)$ to be included in our daily drinks and diets.
\end{abstract}

Key words : Diabetic rats ,hyperlipidimic rats , rosa petals ,serum lipids, liver functions. 
Journal of Home Economics, Volume 27, Number (1), 2017

\section{Introduction}

Diabetes mellitus is a group of metabolic diseases characterized by chronic hyperglycemia resulting from defects in insulin secretion, insulin action, or both. Metabolic abnormalities in carbohydrates, lipids, and proteins resulted from the importance of insulin as an anabolic hormone. Low levels of insulin to achieve adequate response and/or insulin resistance of target tissues, mainly skeletal muscles, adipose tissue, and to a lesser extent, liver, at the level of insulin receptors, signal transduction system, and/or effector enzymes or genes are responsible for these metabolic abnormalities (Craig et al., 2009).

Hyperlipidemia is common in the worldwide population, and is considered as a highly modifiable risk factor for cardiovascular disease such as coronary heart disease and peripheral artery diseases. Elevated blood lipid levels, especially increased serum low-density lipoprotein (LDL) level, can accelerate atherosclerosis. Therefore, reducing high lipid levels has been regarded to be an important approach to prevent or slow the progression of atherosclerosis (Arsenault et al .,2009).

Rosa damascena, commonly known as Damask rose, is known as GoleMohammadi in Iran . It is one of the most important species of Rosaceae family. Rosaceaeare well- known or namental plants and have been referred to as the king of flowers (Nikbakhtet al .,2004). At present time, over 200 rose species and more than 18000 cultivars form of the plant have been identified . Apart from the use of $R$. damascena as ornamental plants in parks, gardens, and houses, they are principally cultivated for using in perfume, medicine and food industry ( Jabbarzadeh and Khosh-Khui .,2005).

Rosa damascena is traditionally used for treatment of abdominal and chest pains, strengthening the heart, menstrual bleeding, digestive problems and constipation. $R$. damascena has an important position in Iranian traditional medicine.It is economically a valuable plant with therapeutic applications in modern medicine. The antimicrobial, antioxidant, analgesic, anti-inflammatory, anti-diabetic and antidepressant properties of $\mathrm{R}$. damascena have been confirmed. Citronellol and geraniol as the main components of $R$. damascena essential oil are responsible for pharmacological activities (Mohaddese,2016).

In traditional Medicines, the decoction of flowers was used for treatment of chest and abdominal pains, menstrual bleeding and digestive ailments (gentle laxative for constipation). It has been famous as 
cardiotonic agent for strengthening the heart(Shahriariet al ., 2006). Rose water traditionally was used as antiseptic agent for eye washing and mouth disinfectingand as antispasmodic agent for alleviating the abdominal pains, and bronchial and chest congestions (Akhmadievaet al .,1992).

The decoctions of dried rose water was used as diuretic and was recommended for reliving the fever, breast pain and menstrual problems. In Iranian traditional medicine, rose petals were cooked with sugar or honey and used for cooling the mind and body. Rose hips were prescribed as blood purifier and also are used by Iranian people with bread( Foster and Duke.,1990).

Thereupon,in the pveseatinvestiqation, the effect of rosa petals powder( rosa damascene) on blood lipids and glucose in experimental rats were studied.

\section{Materials and Methods Materials}

Rosa damascena was purchased from the local market and Sheep"s tail fat were purchased from the local market in shebin EL-kom.Milted and blended it directly with experimental diet formulae andAlloxan were obtained from El-Gomhoriyacampany,for trading Drugs, Chemicals or Medical instruments.

\section{Biological Investigations}

Animals: Fifty-Four Spragu -Dawley strain male albino rats, weighting $150 \pm 10 \mathrm{~g}$ per each were used in this study.All rats were fed the control basal diet for 7 consecutive days. Each rat was housed in an individual stainless steel cage under controlled condition. Diets were introduced to rats in a special non scattering feeding cup to avoid loss of food and contamination. Tap water was provided to rats by means of glass tubes projecting through wire cages from inverted bottles supported to one side of the cage.

\section{Biological experiments}

\section{Basal diet}

The basic diet prepared according to the following formula as mentioned by AIN,(1993) as follow: protein (12\%), corn oil $(10 \%)$,vitamin mixture $(1 \%)$,salt mixture $(4 \%)$,choline chloride $(0.2 \%)$, methionine $(0.3 \%)$,cellulose $(5 \%)$ and the remained is corn starch $(69.5 \%)$. The used vitamin mixure component was that recommended by 
Campbell,(1963) while the salt mixture used formulated according to Hegsted,(1941).

\section{Induction of diabetes mellitus in rats}

Diabetes millets was inducedin normal healthy male albino rats via intraperitoneal injection alloxan $125 \mathrm{mg} / \mathrm{kg}$ body weight according to the method described by Desai and Bhide,(1985). Six hours after the injection ofalloxan ,fasting blood samples were obtained by retro- orbital method to estimate fasting serum glucose. Rats with afasting blood glucose level above $200 \mathrm{mg} / \mathrm{d} 1$ were considered diabetic and were used in this study.

\section{Induction of hyperlipidemia in rats:}

Hyperlipidemia was induced by fed rats on diet containing high lipid (Basal diet $+20 \%$ animal fat sheep's tail)for three consecutive weeks.then fasting blood serum obtained and TC,VLDL, LDL, HDL, and TG,levels were estimated.

\section{Experimental design:}

Forty five adult male albino rats, which fed on basal diet for one week then, divided into three main groups.All groups of rats were fed on the experimental diet for 30 days according to the following :

First group:(5rats)

Rats fed on basal diet only

Second group (diabetic rats):

Diabetic rats were divided into four sub group ( 5 rats per etch) according the following:

Group 1:Rats fed on basal diet as the positive control .

Group2:Rats fed on basal diet containing 1\% Rosa Petals powder (RPP).

Group3:Rats fed on basal diet containing 2.5\%RPP.

Group4::Rats fed on basal diet containing 5\%RPP.

\section{Third group (hyperlipdemeic rats)}

Hyperlipdemeic rats were divided into four sup group(5 rats per each) according the following:

Group 1:Rats fed on basal diet as the positive control

Group2:Rats fed on basal diet containing 1\% RPP.

Group3: Rats fed on basal diet containing 2.5\% RPP

Group4:Rats fed on basal diet containing 5\% RPP

Blood sampling: Blood samples were collected after 12 hour fasting at the end of the experiment. using the retro - orbital method, by means of a microcapillary glass, Blood was collected into a dry clean centrifuge tube, 
and left to clot in a water bath $\left(37^{\circ} \mathrm{C}\right)$ at room temperature for half an hour. The blood was centrifuged for 10 minutes at 3000 r.p.m. to separate the serum. Serum was carefully aspirated and transferred into clean quit fit plastic tubes and kept frozen at $20^{\circ} \mathrm{C}$ until analysis. The liver was removed and washed in saline solution, weighted in neutral buffered formalin solution (10\%) according to methods described by Drury and Wallington (1980). Weight of organs was used to calculate the relative weight $(\%)$ in relation to total body weight.

Biological Indices: Biological evaluation of the different diets was carried out by determination of food intake (FI),body weight gain (BWG\%) and feed efficiency ratio (FER) according to Chapman et al., (1959).

\section{Hematological analysis}

Different tested parameters in serum were determination using specific methods follow: Serum glucose according to Kaplan ,(1984), Lipid cholesterol according toAllain ,(1974), triglycerides (T.G) according to Fassati and Prencipe, (1982), high density lipoprotein (H.D.LC)according toLopez .,(1977), low density lipoprotein (L.D.LC)according to Lee and Nieman ,(1996), Serum glutamate oxaloacetate transaminase S.GOT or (AST) according to Henry, (1974) and Yound,(1975), S.GPT or (ALT) according to Yound,(1975), serum alkaline phosphatase (ALP) according to IFCC, (1983).

\section{Histopathological Examination}

At the end of the experiment which continued for 30 successive days, all rats were sacrificed, tissue samples including liver was taken for histopathological examination according toCarleton, (1978).

\section{Statistical analysis}

Statistical analysis performed by using computer program statistical package for social scienceaccording to(SPSS, 1998).

\section{Results and discussion}

\section{Biological changes:}

Body weight gain (B.W.G\%),Feed intake (F.I), and feed efficiency ratio (F.E.R) ofdiabetic and hyperlipidemic rats:

Table(1) Showed B.W.G(\%),(F.I) and (F.E.R). The mean value of body weight gain (B.W.G\%) of negative control was significantly $(p \leq 0.05)$ higer as compared with positive control, which was71.67 \pm 5.1and $16.95 \pm 1.64 \%$ respectively . whereas the mean value of diabetic treated groups with $1 \%, 2.5 \%$ and $5 \%$ were $47.9 \pm 2.39,57.32 \pm 2.72$, and 
$58.62 \pm 1.13 \%$ respectively. Whereas the mean value of diabetic treated groups $(1 \%, 2.5 \%$ and $5 \%)$ were significantly high $(\mathrm{p} \leq 0.05)$ comparing with positive control.The best BWG\% was for group 5\% RPP.The same table illustrated that the mean value of (F.I) of diabetic treated groups fed on various diets. Results show that the mean value of (FI) of control (+)group was lower than control (-) group it was being14.7 \pm 0 .85and $22.25 \pm 0.85(\mathrm{~g} / \mathrm{day} / \mathrm{rat})$,respectively. Whereas the mean value of diabetic treated groups $(1 \%, 2.5 \%$ and $5 \%)$ didn't show any significantly differnces when compared with control (+). As for as, the mean value of (F.E.R) of diabetic treated groups fed on various diets. Data show that the mean value of (FER) of control (+) group was lower than control (-) group it was being $1.42 \pm 0.07$ and $3.15 \pm 0.85$, respectively ,showing a significant difference. The mean value of FER of diabetic treated groups $(1 \%, 2.5 \%$ and $5 \%)$ were significantly high $(\mathrm{p} \leq 0.05)$ comparing with positive control.

Hyperlipidemic treated groups with $(1 \%, 2.5 \%$ and5\% rosa petals).As shown the mean value of body weight gain (B.W.G\%) of negative control was significantly $(\mathrm{p} \leq 0.05)$ higer as compared with positive control, which was $71.67 \pm 5.1$ and $39.07 \pm 0.48 \%$ respectively. whereas the mean value ofhyperlipidemic treated groups with $1 \%$ and $2.5 \%$ were $37.62 \pm 1.07$ and $37.35 \pm 1.26 \%$ respectively. didn't show any significant difference when compared with positive control.But, group 5\% rosa petals was significantly less $(p \leq 0.05)$ comparing with positive control.

The same table illustrated that the mean value of F.I of negative control was higher significantly $(\mathrm{p} \leq 0.05)$ when compared with positive control , while all hyperlipidimic treated groups show a significant differences comparing with positive control .

As for as , The mean value of FER of control (-) group and All treated groups showed significantly lower when compared with control $(+)$. 
Taple(1): (B.W.G\%), (F.I) and ratio (F.E.R) of diabetic and hyperlipidemic rats:

\begin{tabular}{|c|c|c|c|c|}
\hline \multicolumn{2}{|l|}{ Parameters } & B.W.G(\%) & F.I (g/30 day) & F.E.R \\
\hline \multicolumn{2}{|l|}{ Control(-) } & $71.67 \pm 5.1^{a}$ & $22.25 \pm 0.85^{\mathrm{a}}$ & $3.15 \pm 0.58^{b}$ \\
\hline \multirow{4}{*}{$\begin{array}{l}\text { Diabetic } \\
\text { Groups }\end{array}$} & Control(+) & $16.95 \pm 1.64^{d}$ & $14.7 \pm 0.85^{b}$ & $1.42 \pm 0.07^{\mathrm{c}}$ \\
\hline & $1 \% \mathrm{RPP}$ & $47.9 \pm 2.39^{c}$ & $15.17 \pm 1.25^{b}$ & $4.6 \pm 0.21^{\mathrm{a}}$ \\
\hline & $2.5 \%$ RPP & $57.32 \pm 2.72^{b}$ & $16.75 \pm 1.1^{b}$ & $4.7 \pm 0.14^{\mathrm{a}}$ \\
\hline & $5 \%$ RPP & $58.62 \pm 1.13^{b}$ & $17.5 \pm 0.64^{b}$ & $4.95 \pm 0.15^{\mathrm{a}}$ \\
\hline \multirow{4}{*}{$\begin{array}{l}\text { Hyperlipidimic } \\
\text { Groups }\end{array}$} & Control(+) & $39.07 \pm .48^{\mathrm{b}}$ & $18.92 \pm 1.08^{b}$ & $4.15 \pm 0.25^{\mathrm{a}}$ \\
\hline & $1 \%$ RPP & $37.62 \pm 1.07^{b}$ & $21.75 \pm 0.85^{\mathrm{a}}$ & $3.32 \pm 0.22^{b}$ \\
\hline & $2.5 \%$ RPP & $37.35 \pm 1.26^{b}$ & $23 \pm 1.29^{\mathrm{a}}$ & $3.08 \pm 0.18^{\mathrm{bc}}$ \\
\hline & $5 \%$ RPP & $34.42 \pm 0.46^{\mathrm{c}}$ & $22.45 \pm 1.17^{\mathrm{a}}$ & $2.58 \pm 0.18^{c}$ \\
\hline
\end{tabular}

Values are expressed as, Means \pm SE ; Means in the same raw each group with different superscript letters are significantly difference $(\mathrm{p} \leq 0.05)$

\section{Biochemical changes:}

\section{-Effect of RPP on serum blood glucose of diabetic and hyperlipidemic} rats.

-Table(2) result show the effect feeding on different levels of RPP on serum blood gluocose. As shown in data the table, there were significant decreased in the level of blood glucose, after supplementation with 1,2.5 and 5\%RPP as compared with positive control group in the diabetic and hyperlipidemicrats. The best result was observed in the group fed on the basal diet containing 5\% RPP .these results were in agreement with those reported byGholamhoseinianaet al .,(2009) who showed that rosa petals a dose of $2 \mathrm{glkg}$ body weight significantly decreased of blood glucose level in diabetic rats. The ditet supplemented with dry rose petals had a decrease of glucose concentration of blood .

Taple (2) :Effect of RPP on serum blood glucose of diabetic and hyperlipidemic rats.

\begin{tabular}{|c|c|c|c|c|c|c|c|c|c|}
\hline \multirow[b]{2}{*}{ Parameters } & \multirow{2}{*}{$\begin{array}{c}\text { Control } \\
(-)\end{array}$} & \multicolumn{4}{|c|}{ Diabetic groups } & \multicolumn{4}{|c|}{ Hyperlipidimic groups } \\
\hline & & $\begin{array}{c}\text { Control } \\
(+)\end{array}$ & $\begin{array}{l}1 \% \\
\text { RPP }\end{array}$ & $\begin{array}{l}2.5 \% \\
\text { RPP }\end{array}$ & $5 \%$ RPP & $\begin{array}{c}\text { Control } \\
(+)\end{array}$ & $1 \% \mathrm{RPP}$ & $\begin{array}{l}2.5 \% \\
\text { RPP }\end{array}$ & $\begin{array}{c}5 \% \mathrm{R} \\
\text { PP }\end{array}$ \\
\hline $\begin{array}{l}\text { Serum } \\
\text { Glucose } \\
\text { (mg/dl) }\end{array}$ & $\begin{array}{l}88.5 \pm \\
7.1^{b}\end{array}$ & $\begin{array}{l}191.5 \pm \\
41.77^{\mathrm{a}}\end{array}$ & $\begin{array}{c}125 \pm \\
21.97^{\text {ab }}\end{array}$ & $\begin{array}{r}93 \pm \\
8.53^{b}\end{array}$ & $\begin{array}{l}81.75 \pm \\
8^{.99}\end{array}$ & $\begin{array}{c}97.5 \pm \\
5.6^{\mathrm{a}}\end{array}$ & $\begin{array}{c}\mathbf{8 7 . 2 5} \pm \\
5.58^{b}\end{array}$ & $\begin{array}{c}85.23 \pm \\
3.2^{b}\end{array}$ & $\begin{array}{l}72 \pm \\
2.9^{c}\end{array}$ \\
\hline
\end{tabular}

Values are expressed as, Means \pm SE ; Means in the same column each group with different superscript letters are significantly difference $(p \leq 0.05)$ 
-Effect of different levels of RPP on serum lipid profile (mg /dL)of diabetic and hyperlipidemic rats :

Table (3) result show the effect feeding on different levels of RPP on serum lipid profile. As shown in the table, The levels of TC and TG were significant $(\mathrm{P} \leq 0.05)$ decreasedafter supplementation with RPP (1, 2.5 and $5 \%$ ) as compared with positive control group in the diabetic and hyperlipidemic rats.

Incase of HDL level for diabetic and hyperlipidemicrats after supplemented with RPP ( 1\%,2.5 and5\%) as compared with positive control group. How ever the level of LDL and VLDL were significant $(\mathrm{P} \leq 0.05)$ decreased. Numerically, the best serum TC.TG .HDL, LDL and VLDL was recorded for group5\% RPP when compared to control (-) group. these results were in agreement with those reported byGholamhoseinian et al .,(2012) found that (Rosa damascene)effects on reduction of total cholesterol, triglyceride and low density lipoprotein and plaques formation. It has no effect on high density lipoproteins levels. Therefore, the anti hyperlipidemic effects of $\mathrm{R}$. damascena methanol extract is caused through inhibiting the activities of pancreatic lipase and HMG COA reductase

Taple (3): Effect of different levels of RPP on serum lipid profile (mg /dl) of diabetic and hyperlipidemic rats

\begin{tabular}{|c|c|c|c|c|c|c|c|c|c|}
\hline \multirow{2}{*}{ Parameters } & \multirow[b]{2}{*}{$\begin{array}{c}\text { Control } \\
(-)\end{array}$} & \multicolumn{4}{|c|}{ Diabetic group } & \multicolumn{4}{|c|}{ Hyperlipidimic group } \\
\hline & & $\begin{array}{c}\text { Control } \\
(+)\end{array}$ & $\begin{array}{l}1 \% \\
\text { RPP }\end{array}$ & $\begin{array}{l}2.5 \% \\
\text { RPP }\end{array}$ & $\begin{array}{c}\mathbf{5 \%} \\
\text { RPP }\end{array}$ & $\begin{array}{c}\text { Contr } \\
\text { ol }(+)\end{array}$ & $\begin{array}{l}1 \% \\
\text { RPP }\end{array}$ & $\begin{array}{c}2.5 \% \\
\text { RPP }\end{array}$ & $\begin{array}{l}5 \% \\
\text { RPP }\end{array}$ \\
\hline T.C (mg/dl) & $\begin{array}{l}104 \pm \\
1.95^{\mathrm{c}}\end{array}$ & $\begin{array}{l}141 \pm \\
11.2^{\mathrm{a}}\end{array}$ & $\begin{array}{c}122.25 \pm \\
6^{2.01}{ }^{b}\end{array}$ & $\begin{array}{l}119.25 \\
\pm 3.09^{\mathrm{b}}\end{array}$ & $\begin{array}{l}110 \pm \\
5.4^{\mathrm{bc}}\end{array}$ & $\begin{array}{c}188.5 \pm \\
23.3^{\mathrm{a}}\end{array}$ & $\begin{array}{c}144.7 \pm \\
9.3^{\mathrm{b}}\end{array}$ & $\begin{array}{c}123.5 \pm \\
9.6^{\mathrm{bc}}\end{array}$ & $\begin{array}{l}112 \pm \\
3.6^{\mathrm{c}}\end{array}$ \\
\hline T.G (mg/dl) & $\begin{array}{c}75.7 \pm \\
4.1^{\mathrm{c}} \\
\end{array}$ & $\begin{array}{c}117.75 \pm \\
2.7^{\mathrm{a}} \\
\end{array}$ & $\begin{array}{c}103.7 \pm \\
7.1^{\mathrm{b}} \\
\end{array}$ & $\begin{array}{l}\text { 98.5 } \\
3.1^{\mathbf{b}}\end{array}$ & $\begin{array}{l}78 \pm \\
4.6^{c} \\
\end{array}$ & $\begin{array}{c}154 \pm \\
5.5^{\mathrm{a}} \\
\end{array}$ & $\begin{array}{c}137.7 \pm \\
10.2^{\mathrm{b}} \\
\end{array}$ & $\begin{array}{c}90.25 \pm 4 \\
.5^{\mathrm{c}} \\
\end{array}$ & $\begin{array}{c}81.25 \pm \\
4.6^{c} \\
\end{array}$ \\
\hline HDL (mg/dl) & $\begin{array}{c}47.8 \pm \\
3.3^{\mathrm{a}}\end{array}$ & $35 \pm 0.91^{a}$ & $\begin{array}{c}37.7 \pm \\
0.8^{\mathrm{a}} \\
\end{array}$ & $\begin{array}{c}41 \pm 3 \\
2^{\mathrm{a}} \\
\end{array}$ & $\begin{array}{l}43 \pm \\
3.3^{a} \\
\end{array}$ & $\begin{array}{l}37 \pm \\
1.1^{\mathrm{c}}\end{array}$ & $\begin{array}{c}41.25 \pm \\
0.47^{\mathrm{b}}\end{array}$ & $\begin{array}{c}45.25 \pm 1 \\
.31^{\mathrm{b}} \\
\end{array}$ & $\begin{array}{c}52.25 \pm \\
1.8^{\mathrm{a}}\end{array}$ \\
\hline LDL (mg/dl) & $\begin{array}{c}41.06 \pm \\
1.8^{b} \\
\end{array}$ & $\begin{array}{c}82.45 \pm \\
8.9^{\mathrm{a}} \\
\end{array}$ & \begin{tabular}{|c|}
$64.51 \pm$ \\
$3.4^{b}$ \\
\end{tabular} & $\begin{array}{c}58.55 \pm \\
3.4^{\mathbf{b}} \\
\end{array}$ & $\begin{array}{c}51.4 \pm \\
4^{1} 1^{b} \\
\end{array}$ & $\begin{array}{c}120.7 \pm \\
7.8^{\mathrm{a}} \\
\end{array}$ & $\begin{array}{c}76.05 \pm \\
3.09^{b} \\
\end{array}$ & $\begin{array}{c}60.2 \pm \\
2.9^{\mathrm{b}} \\
\end{array}$ & $\begin{array}{c}43.5 \pm \\
1.3^{\mathbf{c}} \\
\end{array}$ \\
\hline $\begin{array}{l}\text { VLDL } \\
\text { (mg/dl) }\end{array}$ & $\begin{array}{c}15.14 \pm \\
0.9^{b} \\
\end{array}$ & $\begin{array}{c}23.5 \pm \\
0.6^{\mathrm{a}}\end{array}$ & $\begin{array}{c}20.74 \pm \\
1.4^{\mathrm{a}} \\
\end{array}$ & $\begin{array}{c}19.7 \\
\pm 0.8^{\mathrm{a}} \\
\end{array}$ & $\begin{array}{l}15.6 \pm \\
0.96^{b}\end{array}$ & $\begin{array}{c}30.8 \pm \\
1.8^{\mathrm{a}} \\
\end{array}$ & $\begin{array}{l}27.4 \pm \\
2.04^{b} \\
\end{array}$ & $\begin{array}{c}18.05 \pm \\
0.9^{c} \\
\end{array}$ & $\begin{array}{c}16.25 \pm \\
1.17^{\mathrm{c}}\end{array}$ \\
\hline
\end{tabular}

Values are expressed as, means $\pm \mathrm{SE}$; Means in the same column each group with different superscript letters are significantly difference $(\mathrm{p} \leq 0.05)$ 
-Effect of RPP on liver functions in diabetic andhyperlipidemic rats : Data in Table(4): result show the effect feeding on different levels of dry rosa petals isolate on liver functions .The levels of AST ,ALT and ALP were increased in diabetic and hyperlipidemic rats while there were significant decrease $(p \leq 0.05)$ in the activity of these enzymes after supplementation of rats diet RPP $(1,2.5$ and $5 \%)$ as compared with positive control group in the diabetic and hyperlipidemic rats. Numerically, the best serum (AST,ALTand ALP) was recorded for group 5\% RPP when compared to control (-) group.

Table (4) :Effect of RPP on Liver function in diabetic and hyperlipidemic rats :

\begin{tabular}{|c|c|c|c|c|c|c|c|c|c|}
\hline \multirow[t]{2}{*}{ Parameters } & \multirow[b]{2}{*}{$\begin{array}{c}\text { Control } \\
(-)\end{array}$} & \multicolumn{4}{|c|}{ Diabetic group } & \multicolumn{4}{|c|}{ Hyperlipidimic group } \\
\hline & & $\begin{array}{c}\text { Control } \\
(+)\end{array}$ & $\begin{array}{l}1 \% \\
\text { RPP }\end{array}$ & $\begin{array}{c}2.5 \\
\% \\
\text { RPP }\end{array}$ & $\begin{array}{c}\mathbf{5 \%} \\
\text { RPP }\end{array}$ & $\begin{array}{c}\text { Control } \\
(+)\end{array}$ & $\begin{array}{c}1 \% \\
\text { RPP }\end{array}$ & $\begin{array}{l}2.5 \% \\
\text { RPP }\end{array}$ & $\begin{array}{c}\mathbf{5 \%} \\
\text { RPP }\end{array}$ \\
\hline $\operatorname{AST}(\mathbf{U} / L)$ & $\begin{array}{c}169.7 \pm \\
8.6^{\mathrm{c}}\end{array}$ & $\underset{11^{\mathrm{a}}}{223.1 \pm}$ & $\begin{array}{l}217 \pm \\
12.2^{\mathrm{a}}\end{array}$ & $\begin{array}{l}206 \pm \\
10.9^{\mathrm{ab}}\end{array}$ & $\begin{array}{c}187 . \pm \\
9.3^{b}\end{array}$ & $\begin{array}{c}196.7 \pm \\
10.3^{\mathrm{a}}\end{array}$ & $\begin{array}{l}188.2 \pm \\
9.1^{a b}\end{array}$ & $\begin{array}{r}174 \pm \\
9.8^{\mathrm{c}}\end{array}$ & $\begin{array}{c}168.9 \pm \\
6.3^{\mathrm{c}}\end{array}$ \\
\hline$\overline{A L T}(\mathbf{U} / \mathbf{L})$ & $\begin{array}{c}19.75 \pm \\
0.85^{\mathrm{c}}\end{array}$ & $\begin{array}{c}36.3 \pm \\
1.5^{\mathrm{a}}\end{array}$ & $\begin{array}{c}33.6 \pm \\
1.7^{\mathrm{a}}\end{array}$ & $\begin{array}{c}25 \pm \\
1.29^{b}\end{array}$ & $\begin{array}{c}20.75 \pm \\
0.95^{c}\end{array}$ & $33 \pm 1.1^{a}$ & $\begin{array}{c}31.5 \pm \\
1.8^{\mathrm{a}}\end{array}$ & $\begin{array}{c}27 \pm \\
2^{\mathbf{b}}\end{array}$ & $\begin{array}{c}23.3^{\mathrm{c}} \\
2.2^{\mathrm{c}}\end{array}$ \\
\hline $\operatorname{ALP}(\mathbf{U} / \mathbf{L})$ & $49 \pm 1.9^{b}$ & $\begin{array}{l}\text { 70.2 } \\
3.2^{\mathrm{a}}\end{array}$ & $\begin{array}{c}58.6 \pm \\
113^{\mathrm{b}}\end{array}$ & $\begin{array}{c}54.9 \pm \\
5^{\text {b }}\end{array}$ & $\begin{array}{c}47.3 \pm \\
3.8^{b}\end{array}$ & $\begin{array}{l}81.3 \pm \\
3.7^{\mathrm{a}}\end{array}$ & $\begin{array}{c}69.7 \pm \\
3.4^{\mathrm{a}}\end{array}$ & $\begin{array}{c}63.7 \pm \\
3.2^{\mathrm{a}}\end{array}$ & $\begin{array}{l}58 \pm \\
2.6^{a}\end{array}$ \\
\hline
\end{tabular}

Values are expressed as, means \pm SE ; Means in the same columnof each group with different superscript letters are significantly difference $(\mathrm{p} \leq 0.05)$

In Conclusion, rosa petals powder were effective in protecting against diabetic and hyperlipidimic rats not only decreased the level of serum glucose but also has beneficial effect on serum lipids and liver functions Therefore, we recommended this tested plant partby a moderate amount $(5 \%)$ to be included in our daily drinks and diets. 
Journal of Home Economics, Volume 27, Number (1), 2017

\section{C- Histopathological Results:}

\section{C-Liver}

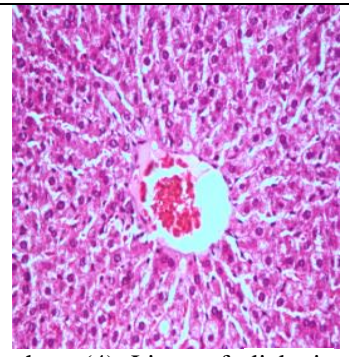

photo:(4) Liver of diabetic rat and treated with drug $1 \%$ showing congestion of the central vein (C) and moderate degeneration (arrow) and necrosis (dashed arrow) of the hepatic cells (H\&E, X 400).

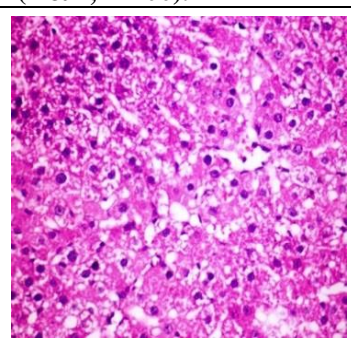

Photo:(8)Liver of hypercholesterolemic rat and treated with drug $(1 \%)$ showing little pit decreased intensity of hepatocellular vacuolar degeneration (arrow) and many necrotic cells (dashed arrow) (H\&E, X400).

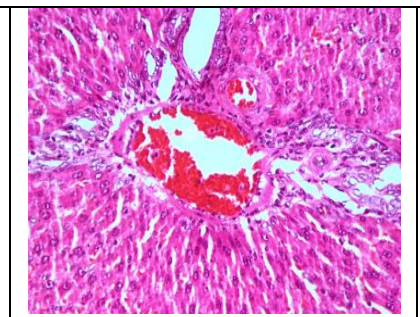

Photo:(3) Portal area in liver of Streptozotocin administrated rat showing congestion of the portal vessels $(\mathrm{P})$ and proliferation of the bile duct epithelium with multiple newly formed bile ducteols (arrow) and oval cell proliferation (dashed arrow) H\&E, X 400).

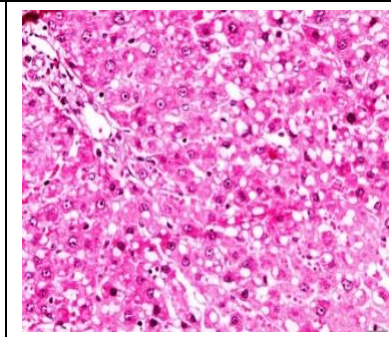

Photo: (7) Liver of hypercholes -terolemic rat showing signe ring appearance (arrow) of the hepatic cells and congested hepatic sinusoids (dashed arrow). (H\&E, X400.

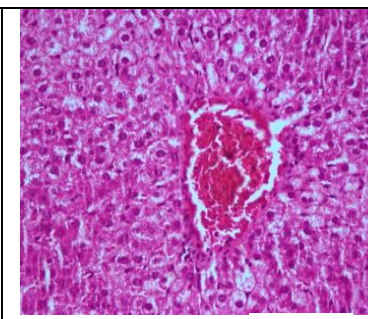

Photo:(2) Liver of Strep tozotocin administrated rat showing severe congestion of the central vein (C) and marked hepatocellular granular and vacuolar degeneration (arrow) and necrotic cells (dashed arrow). (H\&E, X 400).

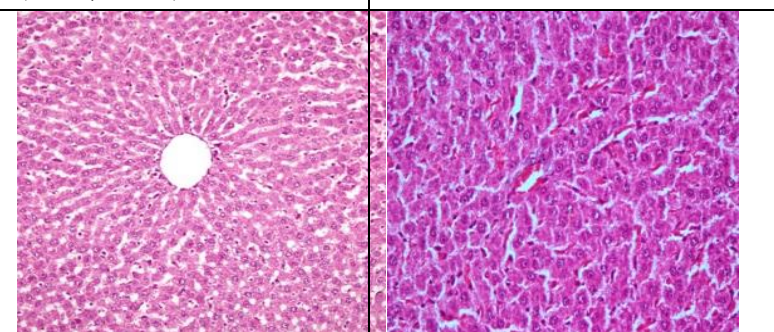

Photo(6): Liver of diabetic rat and treated with drug 5\% showing good restoration of the hepatic parenchymal cells with mild granular degeneration of the hepatocytes and few scattered necrotic cells (arrow). (H\&E, X 200)

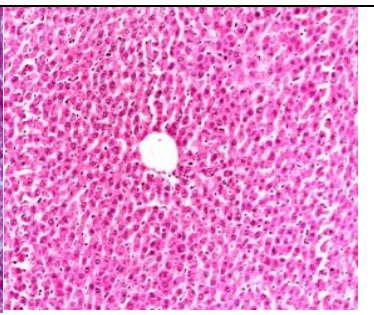

Photo:(1)Liver of control rat showing normal histological structure of hepatic cells $(\mathrm{H})$ and central vein (C). (H\&E, X 200).
Photo:(5) : Liver of diabetic rat and treated with drug $2.5 \%$ showing good restoration of the hepatic parenchyma against the action of Alloxan, only mild congestion (arrow) an moderate degree of hepatocellul moderellular degenerd cells (dashed arrow). (H\&E, X 400).

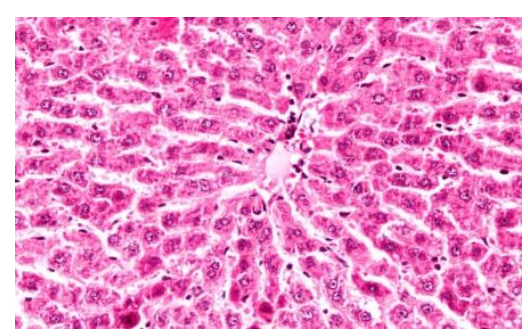

Photo:(10)Liverofhypercholesterolemic rat and treated with drug $(5 \%)$ showing decreased intensity of vacuolar degeneration but with stil moderate necrobiotic changes of the hepatic cells (arrow) with activated Kupffer cells (dashed arrow) and very few apoptotic cells (arrow head). (H\&E, X400).

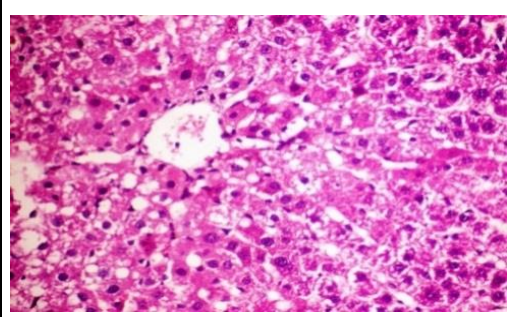

photo:(9) Liver of hypercholesterolemic rat and treated with drug $(2.5 \%)$ showing hepatocellular swelling with moderate degree of vacuolar degeneration (arrow) and granular degeneration (dashed arrow) as well as scattered necrotic cells (arrow head). (H\&E, X400). 


\section{References}

AIN.American Institute of Nutrition. (1993): Purified diet for Iaboratory Rodent. Final report.J.Nutrition.123:193A9-1951

Allain, C.C. (1974): Cholesterol enzymatic colorimetric method .J. of Clin. Chem., (20): 470.

Akhmadieva, A. ;Zaichkina, S.I. ;Ruzieva, R.K. and Ganassi E.E. (1992): The protective action of a natural preparation of anthocyan (pelargonidin-3, 5-diglucoside) Radiobiologiia; 33:433-435.

Arsenault, B.J.;Rana, J.S.;Stroes, E.S. ;Despres, J.P. ; Shah ,P.K. (2009) :Beyond low-density lipoprotein cholesterol: respective contributions of non-high-density lipoprotein cholesterol levels, triglycerides, and the total cholesterol/high-density lipoprotein cholesterol ratio to coronary heart disease risk in apparently healthy men and women. Journal of the American College of Cardiology. 55: 35-41.

Campbell, J. A. (1963): Methodology of Protein Evaluation. RAG Nutr., Document R.10, Led . 37. June Meeting, New york.

Carleton, H.(1979): Histological Techniques. $4^{\text {th }}$ Ed., London, Oxford, New York, Toronto.

Chapman, D. G.; Castilla, R. \& Campbell, J. A. (1959): Evaluation of protein in food. I. A method for the deterinination of protein efficiency ration. Can.J. Biochem. Phosiol., 37: 679-686.

Craig, M. E.; Hattersley, A. \&Donaghue, K.C. (2009): Definition, epidemiology and classification of diabetes in children and adolescents. Pediatr Diabetes.; 10 Suppl 12:3-12.

Desai, A. \&Bhide, M. (1985): Hypoglycemic effect of Hanitoniasuavecolens. Idian J. Med., 81: 86 - 91.

Drury, R. A. B. \& Wallington, E. A. (1980): Carlton's Histolotical Technique.5th Ed., Oxford University.

Fassati, P.\&Prencipe, L. (1982): Triglyceride enzymatic colorimetric method .J. of Clin. Chem., 28:2077.

Foster ,S.\& Duke, J.A.( 1990): Rosa rugosa Thunb. In Medicinal Plants. New York, NY.

Gholamhoseinian, A.; Fallah, H.;Sharififar, F. (2009):Inhibitory effect of methanol extract of Rosa damascena Mill. Flowers on aglucosidase activity and postprandial hyperglycemia in normal and diabetic rats.Phytomedicine., 16:935-941. 
Gholamhoseinian, A.; Shahouzehi, B.; Joukar, S.(2012): Iranpoor M. Effect of Quercusinfectoria and Rosa damascena on lipid profile and atherosclerotic plaque formation in rabbit model of hyperlipidemia. Pak J Biol Sci.,15:27-33.

Hegsted, D.; Mills, R. \& Perkins, E. (1941): Salt mixture. J. Biol. Chem., 138: 459.

Henry, R. J; Cannon, D.C. and Winkelman, J.W. (1974): Clinical Chemistry, Principles and Techniques. $2^{\text {nd }}$ Ed., Harper and Row.

International Federation of Clinical Chemistry (IFCC) (1983):Methods for the measurement of catalytic concentration of enzymes, part 5: IFCC, methods for alkaline hosphatase. J. Clin. Chem.Clin. Biochem., 21: 731-748.

Jabbarzadeh, Z.andKhosh-Khui ,M. (2005):Factors affecting tissue culture of Damask rose (Rosa damascena Mill.) SciHortic. 105:475-482. Factors affecting tissue culture of Damask rose (Rosa damascena Mill.) SciHortic. 105:475-482.

Kaplan, L. A. (1984): Clinical Chemistry. The C.V.Mosby Co. St Louis.Toronto.Princeton, PP1032-1036.

Lee, R. \&Nieman, D. (1996): Nutritional Assessment. $2^{\text {nd }}$ Ed.,Mosby, Missouri,MI.

Lopez, M. F. (1977): HDL-cholesterol colorimetric method. J. of Clin. Chem., 23:882.

Mohaddese ,M .(2016): Rosa damascena as holy ancient herb with novel applications. J .Tradit Complement Med.Jan.6(1): 10-16.

Nikbakht, A.; Kafi ,M.; Mirmasoudi, M.; Babalar, M.(2004): Micropropagation of Damask rose (Rosa damascena Mill) cvsAzaran and Ghamsar. International $\mathbf{J}$ of Agriculture and Biology;7(4):535-538.

Shahriari ,S.; Yasa, N.; Mohammadirad, A.;Khorasani, R.; Abdollahi, M. (2006):In vivo antioxidant potentials of Rosa damascena petal extract from Guilan, Iran, comparable to atocopherol. Int J Pharmacol.,3:187-190.

SPSS (1998): Statistical Package for Social Science, Computer Software, Ver. 10, SPSS Company. London, UK.

Yound, D. S. (1975): Determination of GOT. J. Clin .Chem.; 21:1. 


\title{
دراسة تأثيرمسحوق بتلات الورد المجفف علي دهون وسكر الدم في فئران التجارب
}

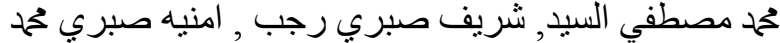

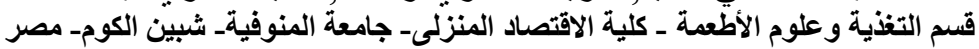

تم اجر اء هذه الدراسة لمعرفه تأثثر بتلات الورد علي دهون وسكر الدم في فئران

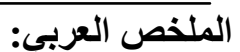

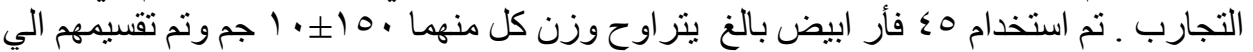

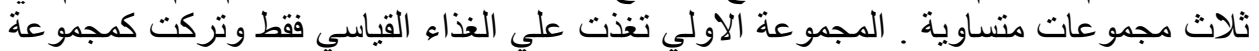

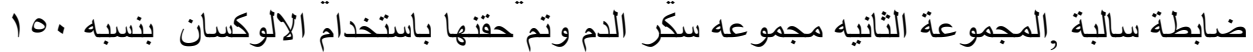

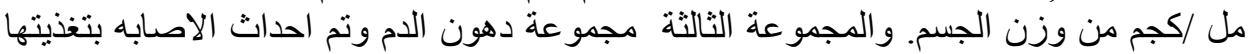

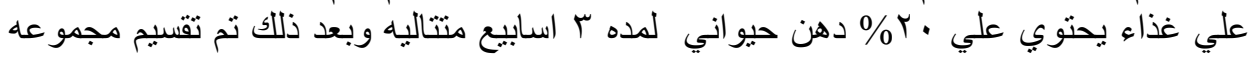

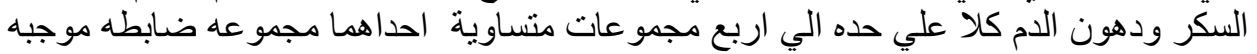

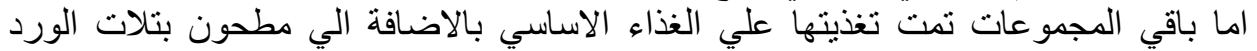

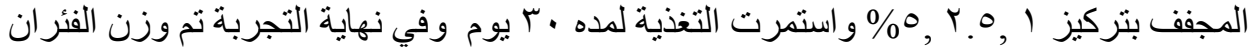

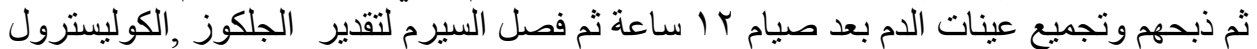

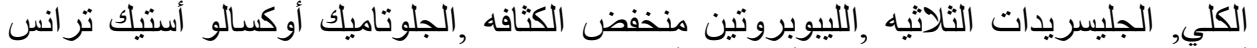

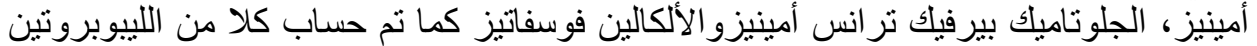

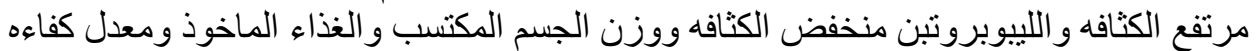

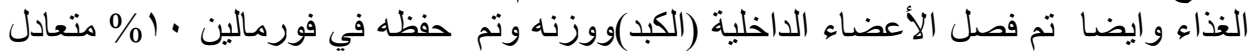

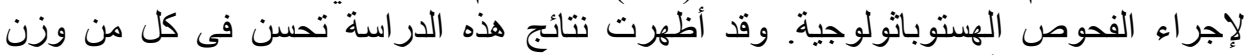

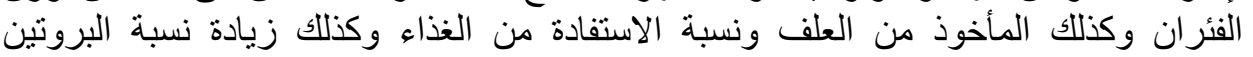

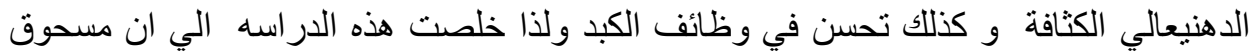

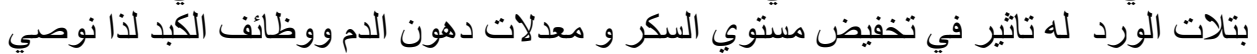

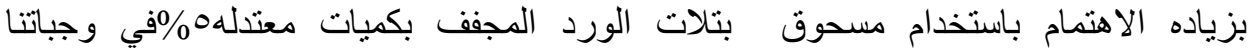

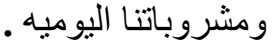

الكلمات المفتاحيه :الفئران المصابه بالسكري ,الفئران المصابه بارتفاع بدهون الدم ,مسحوق بتلات الورد ,وظائف الكبد. 